\title{
Infrared Thermography Applied to the Evaluation of Metabolic Heat Loss of Chicks Fed with Different Energy Densities
}

-Author(s)
Ferreira VMOS1
Francisco NS ${ }^{1}$
Belloni M1
Aguirre GMZ1
Caldara FR²
Nääs IA ${ }^{2}$
Garcia RG ${ }^{2}$
Almeida Paz ICL²
Polycarpo GV 3
1 Graduate student in Animal Science,
Universidade Federal da Grande Dourados,
Faculdade de Ciências Agrárias.
2 Professor, Universidade Federal da Grande
Dourados (UFGD), Faculdade de Ciências
Agrárias (FCA). Dourados, MS, Brazil.
3 Pos Graduate Student in Animal Science,
FAPESP grantee, Veterinary Medicine and
Animal Science School, São Paulo State
University (UNESP). Botucatu, SP, Brazil.
E-mail: gupolycarpo@hotmail.com

\section{Mail Adress}

Viviane Maria Oliveira dos Santos Ferreira Universidade Federal da Grande Dourados Faculdade de Ciências Agrárias

Caixa Postal 533

79.804-970. Dourados, MS, Brazil.

E-mail: eviviane@hotmail.com irenilza@gmail.com

\section{nKeywords}

Energy-dense diet, infrared thermal imaging, metabolic heat, poultry, wellbeing.

\begin{abstract}
Brazil must comply with international quality standards and animal welfare requirements in order to maintain its position as world's largest exporter of poultry meat. With the scenario of global climate change there is the forecast of occurrence of extreme events with characteristics of both excess cold and heat for several regions of the country. This study aimed to evaluate the effectiveness of using images of infrared thermography to evaluate the loss of sensible heat in young broilers fed different dietary energy levels. Twenty birds were reared in a house with appropriate brooding using infrared lamps. Birds were distributed in a completely randomized experimental into two treatments: T1 (control diet with $2950 \mathrm{kcal} \mathrm{ME} / \mathrm{kg}^{-1}$ ), and T2 (high-energy diet with $3950 \mathrm{kcal} \mathrm{ME} / \mathrm{kg}^{-1}$ ). Infrared thermographic images of the birds were recorded for four consecutive days. One bird was randomly chosen per treatment, and had special images taken and analyzed. Average surface temperature of the body area was calculated using the surface temperature recorded at 100 spots ( 50 at the front and 50 at the lateral side of the bird's body). Mean surface temperature of the flock was calculated recording 100 spots on the group of birds. Total radiant heat loss was calculated based on the average data of surface temperature. The results indicated that the young broilers fed the high-energy diet presented a metabolic energy loss equivalent to $0.64 \mathrm{kcal} \mathrm{h}^{-1}$, while the birds fed with the control diet lost $2.18 \mathrm{kcal} \mathrm{h}^{-1}$. This finding confirms that oil supplementation to the diet reduces bird heat loss. The infrared camera was able to record young broilers' surface temperature variation when birds were fed diets with different energy contents.
\end{abstract}

\section{INTRODUCTION}

Brazil produced almost 11 million tons of chicken meat in 2009, out of which $70 \%$ was exported, making it the leading poultry exporter in the world (UBA, 2009). In order to keep this position, the Brazilian production chain must make constant innovations to meet international quality standard requirements. In addition, the world's largest chicken meat importers have set deadlines for the compliance of requirements for intensive production systems, including those related to housing environment and animal welfare.

When the housing environment not within the thermoneutral zone, metabolic heat dissipation of poultry changes. The thermal tolerance of broilers varies according to age and weight. The thermal comfort zone of 1 to 7 -d-old broilers is around $31-33^{\circ} \mathrm{C}$, and it is reduced to $21-23^{\circ} \mathrm{C}$ when they are 35 to 42 days old, considering that air relative humidity is between 65 and 70\% (Furlan \& Macari, 2002). The main effects of exposure to excessive cold or heat is high flock mortality and changes in feed intake, both of which have undesirable economic 
Ferreira VMOS, Francisco NS, Belloni M, Aguirre GMZ, Caldara FR, Nääs IA,

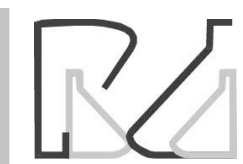

Infrared Thermography Applied to the Evaluation of Metabolic Heat Loss of Chicks Fed with Different Energy Densities consequences (Rutz, 1994). One of the strategies adopted to overcome the problem of reduced feed intake is to increase dietary energy density by replacing carbohydrates for fat. The use of fat is justified by the fact that it presents lower heat increment as compared to other nutrients (Ribeiro \& Laganá, 2002).

Global climate change has increased the frequency of extreme weather events (IPCC, 2010), and it is necessary to know the optimal ranges of environmental variables to provide proper housing environment to poultry. Infrared thermography is a recent technology used to evaluate housing thermal conditions and their influence on the wellbeing of animals. This technology has been efficiently used to monitor the metabolic activity of domestic and wild animals by recording the surface temperature and by quantitatively and qualitatively evaluating heat flow (Klir et al., 1988; Klir \& Heath, 1992; Phillips \& Sanborn, 1994; McCafferty et al., 1998; Phillips \& Heath, 2001). This technique has the advantage of being non-invasive and nondestructive (Eddy, 2001).

The aim of this study was to record radiant heat exchange of young broilers fed diets containing different energy levels, and to evaluate the effectiveness of an infrared thermography camera to record broiler metabolic activity by calculating its surface temperature.

\section{MATERIALS AND METHODS}

The experiment was carried out at the Grande Dourados Federal University (UFGD), Dourados, MS, Brazil, located at $430 \mathrm{~m}$ altitude, $22^{\circ} 13^{\prime} 16^{\prime \prime} \mathrm{S}$ latitude and $54^{\circ} 48^{\prime} 20^{\prime \prime} \mathrm{W}$ longitude. In this region, the summer is hot and humid, with average minimum temperature of $20 \pm 1{ }^{\circ} \mathrm{C}$, and the winter is cold and dry, with average minimum temperature of $14.3 \pm 1{ }^{\circ} \mathrm{C}$.

\section{Birds and management}

Twenty male Ross ${ }^{\circledR}$ broilers were reared from 1-7 days of age in an experimental broiler house $(50 \mathrm{~m}$ long, $10 \mathrm{~m}$ wide and $3 \mathrm{~m}$ high) divided into 56 pens of $4.5 \mathrm{~m}^{2}$ each, with a central brooding circle of $2.5 \mathrm{~m}$ diameter. Houses were equipped with double curtains to control excessive wind and to keep internal temperature close to the thermoneutral zone. Brooding was done using $250 \mathrm{~W}$ infrared lamps in each circle within each pen. Artificial lighting was provided by $40 \mathrm{~W}$ bulbs during $24 \mathrm{~h}$ during the entire experimental period, resulting in an average light exposure of 221x. Water was offered ad libitum in bell drinkers and feed in tube feeders. Environmental data were collected in the database of Embrapa (2010) and house and brooding circle temperatures were recorded in the geometric center of the pens. Diets were formulated on corn and soybean meal basis to supply birds' nutritional requirements as proposed by Rostagno et al. (2005), except for energy intake, which varied according to treatments. Increasing dietary energy content was obtained by the supplementation of soybean oil.

\section{Experimental design and statistical analysis}

Birds were distributed in a completely randomized experimental design into two treatments:

T1 - control diet with $2950 \mathrm{kcal} \mathrm{EM} \mathrm{kg}^{-1}$;

T2 - high-energy diet with $3950 \mathrm{kcal} \mathrm{EM} \mathrm{kg}^{-1}$;

Data were submitted to analysis of variance and means were compared by the test of Tukey at 95\% probability level using the statistical program SAS (2001).

\section{Estimation of thermal load}

After two days of adaptation to the experimental diets, infrared thermal images of the birds were taken using an infrared camera (Testo ${ }^{\circledR} 880$ ), with an accuracy of $\pm 0.1^{\circ} \mathrm{C}$ and 7.5 to $13 \mathrm{mM}$ infrared spectrum range, during four consecutive days, always at 15h:00min. In addition to flock images, one bird per treatment was randomly chosen to record infrared thermal images of its body in order to determine its surface temperature. A coefficient of emissivity of 0.86 was used for the entire body surface of the bird (Nääs et al., 2010). Average surface temperature and standard deviation of body surface area were calculated using the temperature of 100 randomly-selected spots in the infrared thermographic image (50 in the front and 50 in the lateral side of the bird's body) and 100 spots of the entire flock (Figure 1).

Using the infrared thermographic images, bird heat loss by radiation (Qr) was calculated using Equation 1 (Meijerhof \& Van Beek, 1993; Yahav et al., 2004):

$$
\mathrm{Qr}=\varepsilon \sigma \mathrm{A}\left(\mathrm{Ts}^{4}-\mathrm{Ta} \mathrm{a}^{4}\right)
$$

where: $\mathrm{Qr}=$ heat loss by radiation $(\mathrm{W}) ; \varepsilon=$ emissivity of biologic tissue (0.86); $\sigma=$ Stefan Boltzmann Constant $\left(5.6710^{-8} \mathrm{~W} \mathrm{~m}^{-2} \mathrm{~K}^{-4}\right)$; $\mathrm{A}=$ bird surface area $\left(\mathrm{m}^{2}\right)$; Ts = bird surface temperature $(C)$, and $\mathrm{Ta}=$ air temperature (C).

Bird surface area was calculated using data from the image shapes (Figures $2 a$ and $b$ ) of the following parts (in 3D): head (sphere), body (oval) and leg (side wall of cylinder), as indicated by Neves et al. (2009). 


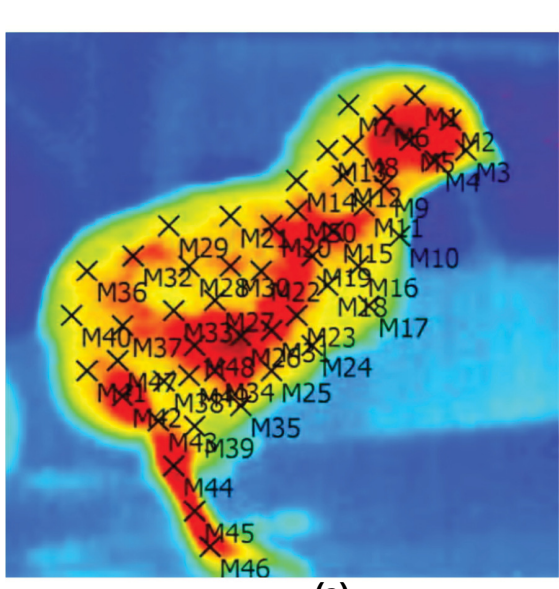

(a)

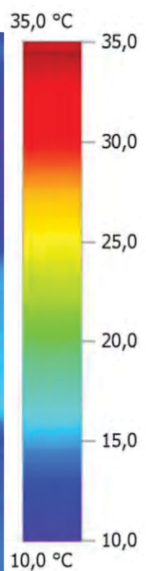

$10,0^{\circ} \mathrm{C}$

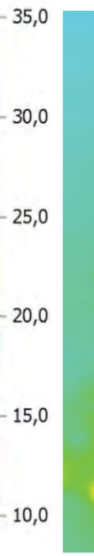

,

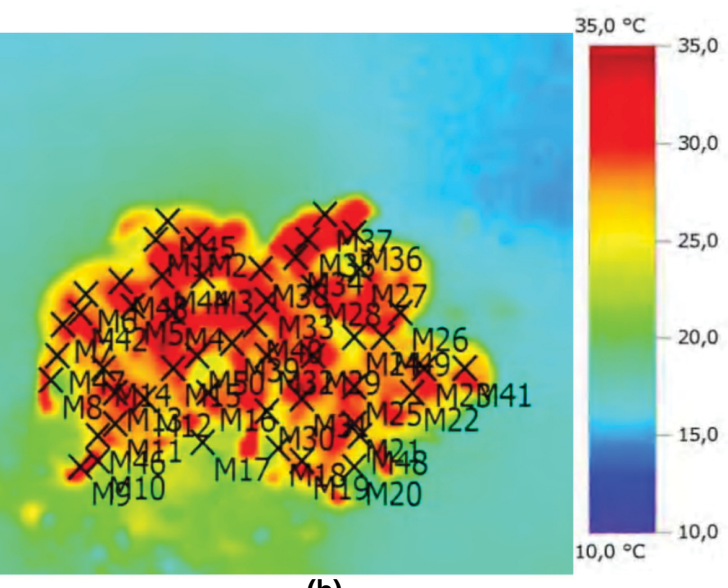

(b)

Figure 1 - Spots where surface temperature was collected in thermographic images of individual broilers (a) and of the flock (b).

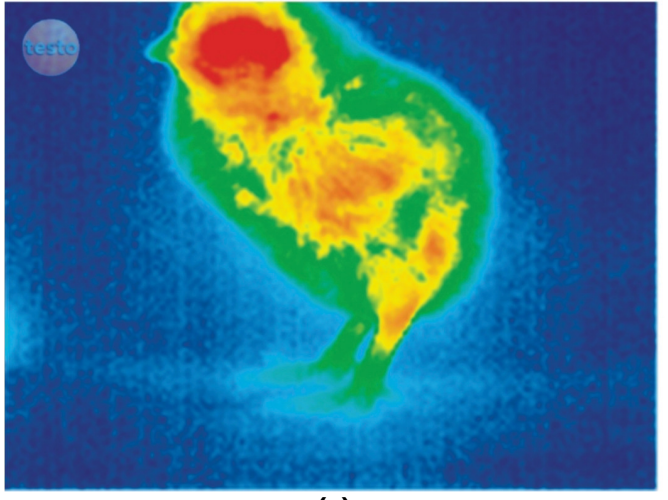

(a)

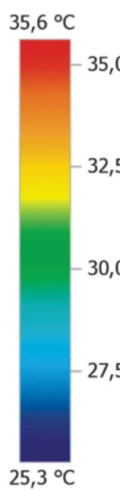

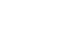

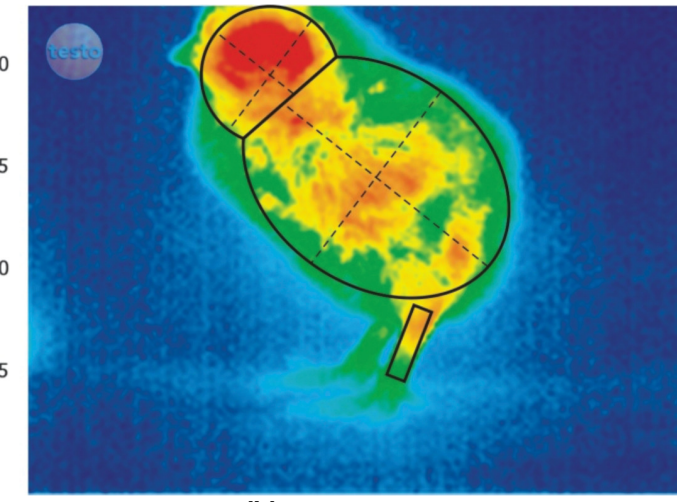

(b)

Figure 2 - Broiler infrared thermographic image (a), and the diagram used to process bird body surface area (b). Source: Neves et al. (2009).

Air dry temperature was recorded using a digital thermometer, and wet bulb temperature was calculated applying the program Psicrom ${ }^{\circledR}$ (Roriz, 2003), using records of relative humidity and temperature data collected from the database of Embrapa (2010).

\section{RESULTS AND DISCUSSION}

During the experiment, environmental temperature ranged between 8.4 and $9.8{ }^{\circ} \mathrm{C}$ and the recorded relative humidity was between $63 \%$ and $95 \%$ (Table 1). Average temperature below the brooder was 27 ${ }^{\circ} \mathrm{C}$. According to Nicholson (2004), the recommended temperature for broilers during brooding is 32.0 and $35.0{ }^{\circ} \mathrm{C}$, which was not achieved due to the severe cold weather that occurred during the experiment.

Although the advantage of oil addition to the diet is significant in periods of high ambient temperature (Baião \& Lara, 2005; Simsek et al., 2009) the main objective of this study was to assess the efficiency of an infrared thermographic camera to detect variations in metabolic heat production as a function of dietary energy, independently of weather conditions. The higher dietary energy level of the diet containing soybean oil resulted in lower metabolic heat production, as demonstrated by the difference between treatments in mean surface temperature of individual birds ( $p$ $<0.02$ ) and of the entire flock ( $<<0.01$, Table 2$)$.

Table 1 - Outside air temperature (TO), air temperature inside the pen (TI) and bird surface temperature (TS).

\begin{tabular}{cccc}
\hline \multirow{2}{*}{ Day of data recording } & \multicolumn{3}{c}{ Temperature $\left({ }^{\circ} \mathbf{C}\right)$} \\
\cline { 2 - 4 } & TO & TI & TS \\
\hline 1 & 9.3 & 16 & 27 \\
2 & 9.8 & 14.5 & 27 \\
3 & 8.4 & 14.5 & 27 \\
4 & 8.4 & 14 & 27 \\
\hline
\end{tabular}

When evaluated separately from the flock, individual surface temperature was lower and independent of dietary energy level, suggesting that the clustering of birds allowed the reduction of radiant heat loss, (measured by the thermographic camera (Shinder et al. 2007; Moura et al., 2008). 
Ferreira VMOS, Francisco NS, Belloni M, Aguirre GMZ, Caldara FR, Nääs IA, Garcia RG, Almeida Paz ICL, Polycarpo GV
Infrared Thermography Applied to the Evaluation of Metabolic Heat Loss of Chicks Fed with Different Energy Densities
Table 2 - Surface temperature of flocks and individual broilers fed diets with different energy levels.

\begin{tabular}{|c|c|c|c|c|}
\hline & T1 & $\mathrm{T} 2$ & $p$-value & CV (\%) \\
\hline Flock & $29.00 a$ & $27.97 b$ & 0.0001 & 9.68 \\
\hline Individual & $27.33 a$ & $26.71 \mathrm{~b}$ & 0.0219 & 12.29 \\
\hline Mean & 28.17 & 27.34 & & \\
\hline
\end{tabular}

Considering the average environmental temperature of $27.0^{\circ} \mathrm{C}$ under the brooder, the calculated heat loss by radiation was $0.74 \mathrm{~W}$ for the birds fed the diet supplemented with oil, while those fed the control diet presented $2.54 \mathrm{~W}$ radiant heat loss. This indicates that the infrared thermal camera was effective in identifying the reduction in metabolic heat production of birds fed diets with higher energy content by oil supplementation.

Radiation is a form of heat loss through infrared rays that involves the transfer of heat from one object to another without any physical contact, and it is important in determining the emissivity of the actual skin temperature (Ring, 1995). Skin emissivity varies from 0.86 to 0.98 (Hejazi et al., 1992; Nääs et al., 2010). The body of a warm-blooded (homeothermal) animal can be divided into core, which temperature is kept within narrow ranges and independently from environmental temperature, and a peripheral area, which temperature is strongly influenced by environmental temperature (Wenger, 1996).

Metabolic heat is produced inside the body and distributed throughout the body by the bloodstream. It is transported by conduction to the surface of the body (Fiala et al., 1999) and it is lost to the environment in the form of sensible (radiation, convection and conduction) and latent (evaporation) heat when the environmental temperature is lower than the animal's body temperature. When the environment is hot, there is peripheral vasodilatation, which increases blood flow to the skin, thereby promoting the dissipation of body heat to the environment. In contrast, when the environment is cold, there is peripheral vasoconstriction to limit the amount of heat brought by the blood to the skin surface, reducing which reduces heat loss to the environment (Gray, 1997).

Calculating heat loss by radiation in $\mathrm{kcal}$, birds in T1 presented a heat loss equivalent to $0.64 \mathrm{kcal} \mathrm{h}^{-1}$, whereas those in $\mathrm{T} 2$ had $2.18 \mathrm{kcal} \mathrm{h}^{-1}$ heat loss. This indicates that the increase in dietary oil content may reduce metabolic heat production in broilers, and therefore may be an interesting alternative to alleviate heat stress during periods of high environmental temperature. Environmental temperature and relative humidity $(\mathrm{RH})$ directly influence sensible and latent heat loss (Brossi, 2009).

Environmental temperature is considered the most important physical factor affecting the performance of broiler chickens since it exerts significant influence on feed intake (Teeter et al., 1984), thereby directly affecting weight gain and feed conversion. Reductions in feed or metabolic substrate intake decrease fuel available for metabolism, thereby reducing heat production. Thus, a diet formulated for thermal neutral conditions would not be adequate to supply the energy requirements of birds reared in heat stress environments (Oliveira et al., 2000).

The direct visual determination was only possible with the use of infrared thermography, which is the recommended method for direct assessment. It allows obtaining the temperature of a surface by quantitatively measuring thermal radiation emitted from certain surface, and it also accurately detects small variations in skin temperature (Maldague, 2001). Another advantage of using infrared thermographic images, as compared to other temperature measurement methods, is that it allows the simultaneous acquisition of a large number of photo elements (pixels) in a very short time and real-time image processing (van den Heuvel et al., 2003).

Heat loss in poultry was evaluated by Yahav et al. (2004), who found significant physiological changes when the thermal and metabolic balances were affected. A more precise estimation of heat production during broiler rearing, from hatching to slaughter, may allow the formulation of diets that meet more precisely broiler requirements, stimulating their intake during periods of high environmental temperature, and studies such as the present one may contribute to this type of feed formulation.

\section{CONCLUSIONS}

Infrared thermography analysis effectively identified the metabolic activity of broilers fed diets with different energy levels and reared under low environmental temperatures by recording their surface temperature.

\section{REFERENCES}

Baião NC, Lara LJC. Oil and fat in broiler nutrition. Revista Brasileira de Ciência Avícola / Brazilian Journal of Poultry Science 2005; 7 (3):129-141.

Brossi C, Contreras-Castilho CJ, Amazonas EA. Estresse térmico 
durante o pré-abate em frangos de corte. Ciência Rural 2009; 39 (4):1296-1305

Eddy AL, Hoogmoed VLM, Snyder JR. The role of thermography in the management of equine lameness. The Veterinary Journal $2001 ; 162: 172-181$

Embrapa. Clima Dourados MS. Dourados: Agropecuária Oeste [citado 2010 nov. 04]. Disponível em: http://www.cpao.embrapa. br/clima/index.php?pg=base_dados.

Fiala D, Lomas KL, Stohrer MA. Computer model of human thermoregulation for a wide range of environmental conditions: the passive system. Journal of Applied Physiology 1999; 87(5): 1957-1972.

Furlan RL, Macari M. Termorregulação. In: MACARI, M, FURLAN RL. Fisiologia aviária aplicada a frango de corte. 2 ed. Jaboticabal: FUNEP; 2002. p.209-230.

Gray J. The world of skin care. P\&G Skin Care Research Center; 1997 [cited 2010 jul.]. Available from: http://www.pg.com/science/ skincare/.

Hejazi S, Wobschall DC, Spangler RA, Anbar M. Scope and limitations of thermal imaging using multiwavelength infrared detection. Optical Engineering 1992; 31(11):2383-2392.

Intergovernmental panel on climate change IPCC. Expert meeting on assessing and combining multi model climate projections [cited 2010 april]. Available from: http://www.ipcc.ch/pdf/ supporting-material/expert-meeting-assessing-multi-modelprojections-2010-01.pdf

Klir JJ, Heath JE, Bennami N. An infrared thermographic study of surface temperature in relation to external thermal stress in the Mongolian gerbil (Meriones unguiculatus). Company Biochemical Physiology 1988; 96(1):141-146.

Klir JJ, Heath JE. Aninfrared thermographic study of surface temperature in relation to external thermal stress in three species of foxes: there red fox (Vulpes vulpes), Artic fox (Alopex lagopus), and kit fox (Vulpes macrotis). Physiology Zoology 1992; 65:10111021.

Maldague XPV. Theory and practice of infrared technology for non destructive testing. New York: John-Wiley \& Sons; 2001. p.684.

Meijerhof R, Van BG. Mathematical modeling of temperature and moisture loss of hatching eggs. Journal of Thermal Biology 1993; 165:27-41

McCafferty DJ, Moncrieff JB, Taylor IR. The use of IR thermography to measure the radiative temperature and heat loss of a barn owl (Tyto alba). Journal of Thermal. Biology 1998; 23:311-315.

Moura DJ, Nääs IA, Alves, ECS, Carvalho TMR, Vale MM, Lima $\mathrm{KAO}$. Noise analysis to evaluate chick thermal comfort. Scientia Agricola 2008; 65 (4):438-443.

Nääs IA, Romanini CEB, Neves DP, Nascimento GR, Vercelino RA. Broiler surface temperature districution of 42 day old chikens. Scientia Agricola 2010; 5:497-670
Neves DP, Romanini CEB, Nascimento GR, Nääs IA, Menezes AG. Estimativa da perda de calor em pintos de um dia dentro do incubatório. Anais do $38^{\circ}$ Congresso Brasileiro de Engenharia Agrícola; 2009; Juazeiro, Bahia. Brasil.

Nicholson FA, Chambers BJ, Walker A. Ammonia emissions from broiler litter and laying hen manure management systems. Biosystems Engineering 2004; 89(2):175-185

Oliveira RFM, Zanusso JT, Donzele JL. Níveis de energia metabolizável para frangos de corte de 1 a 21 dias de idade mantidos em ambiente de alta temperatura. Revista Brasileira de Zootecnia/ Brazilian Journal of Animal Science 2000; 29(3):810816

Phillips PK, Heath JE. An infrared thermographic study of surface temperature in the euthermic woodchuckz (Marmota monax). Comparative Biochemistry and Physiology 2001; 129:557-562.

Ring EFJ. Thermal imaging of skin temperature. In: Serup J, Jemec $\mathrm{G}$, editors. Handbook of non-invasive methods and the skin. Boca Raton: CRC Press; 1995. p.457-71.

Rostagno HS, Albino LTF, Donzele JL, Gomes PC, Oliveira RF, Lopes DC, Ferreira AS, Barreto SLT. Tabelas brasileiras para aves e suínos: composição de alimentos e exigências nutricionais. 2.ed. Viçosa: UFV, Departamento de Zootecnia; 2005. p.186

Roriz M. Psicrom 1.0 - Relações psicométricas. São Carlos: Universidade Federal de São Carlos, Departamento de Engenharia Civil; 2003.

Ribeiro AML, Laganá C. Estratégias nutricionais para otimizar a produção de frangos de corte em altas temperaturas [cd rom]. Anais do $1^{\circ}$ Encontro Internacional de Negócios da Pecuária; 2002; Cuiabá, MT. Brasil.

Shinder D, Rusal M, Tanny J, Druyan S, Yahav S. Thermoregulatory responses of chicks (Gallus domesticus) to low ambient temperatures at an early age. Poultry Science 2007; 86:2200-2209.

Simsek UG, Cerci H, Dalkilic B, Yilmaz O, Ciftci M. Impact of stocking density and feeding regimen on broilers: Chicken meat composition, fatty acids, and serum cholesterol levels. Journal of Applied Poultry Research 2009; 18 (3):514-520.

Rutz F. Aspectos fisiológicos que regulam o conforto térmico de aves. Anais da Conferência Apinco 1994 de Ciência e Tecnologia Avícola; 1994. Santos, São Paulo. Brasil. p.73-84.

SAS Institute. SAS user's guide. Cary: SAS Institute; 2001

Teeter RG, Smith MO, Murray E. Force feeding methodology and equipament for poulty. Poultry Science 1984; 63(4):573-575

UBA - União Brasileira de Avicultura. Últimos números na avicultura [citado 2010 jul. 29]. Disponível em: http//: www.uba.org.br.

Van den Heuvel CJ, Ferguson SA, Dawson D, Gilbert SS. Comparison of digital infrared thermal imaging (DITI) with contact thermometry: pilot data from a sleep research laboratory. Physiology 2003; 24:717-725. 
Ferreira VMOS, Francisco NS, Belloni M, Aguirre GMZ, Caldara FR, Nääs IA,

Garcia RG, Almeida Paz ICL, Polycarpo GV

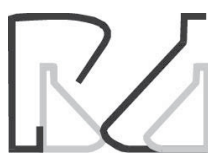

Infrared Thermography Applied to the Evaluation of Metabolic Heat Loss of Chicks Fed with Different Energy Densities

Wenger CB. Human responses to thermal stress [technical note 96-3]. Army: Research Institute of Environmental Medicine; 1996. p.1-70.

Yahav S, Straschnow A, Luger D, Shinder D, Tanny J, Cohen S. Ventilation, sensible heat loss, broiler energy, and water balance under harsh environmental conditions. Poultry Science 2004; 83: 253-258. 